DOI: $10.2478 / \mathrm{v} 10025-008-0001-6$

JOURNAL OF WATER

AND LAND DEVELOPMENT

J. Water Land Dev. No. 11, 2007: 3-16

\title{
Irrigation in Poland - current status after reforms in agriculture and future development
}

\author{
Leszek $Ł A B E \subset D Z K I$
}

Institute for Land Reclamation and Grassland Farming at Falenty, Regional Research Center in Bydgoszcz, Glinki 60,85-174 Bydgoszcz, Poland; imuzbyd@by.onet.pl; labl@poczta.onet.pl

\begin{abstract}
The paper characterizes the status, trends and perspectives of irrigation in Poland after the reforms in agriculture and technology. Irrigation in Poland has supplemental character. It is used in short periods during the growing season and plays an important role in mitigating the effects of drought on crop production. Sub-irrigation from ditches is applied on permanent grasslands, sprinkling - in field cultivation of arable crops, sprinkling and drip irrigation - in vegetable growing in open areas, micro-jets and drip irrigation systems - in orchards. Drip irrigation and micro-jets systems are also applied in plant cultivation in greenhouses.

Under the economic conditions of Polish agriculture irrigation is often an unprofitable measure. The existing irrigation systems and facilities are only used to a small extent. After changes in the forms of ownership in agriculture, the large-area sprinkling systems were degraded. Small irrigation systems, mainly drip irrigation and micro-sprinkler irrigation, have recently become more common in private farms. Sub-irrigation systems are largely degraded and used only to a small extent if at all. In order to use these systems more effectively, it is necessary to reconstruct and modernize them. In many cases the factor preventing the use of irrigation systems is the deficit of water of required quality and its availability. Besides unfavourable economic conditions, it is one of the main limitations in the development of irrigation in Poland.
\end{abstract}

Key words: agriculture, irrigation, irrigation systems, maintenance, management, operation

\section{INTRODUCTION}

The new economical situation after 1989 - opening of the Polish market to the subsidised agriculture production of the EU and internal tax policy towards stateowned farms deteriorated the existence of farmers' families, particularly of agricultural workers and initiated new tendencies in the functioning of agriculture.

The transformation of the Polish agriculture in the 1990s concerned mainly the state-owned farms, which occupied $18.5 \%$ of the agricultural area in 1989. As a result of the selling/buying and leasing transactions, the area of land remaining in the public sector in 2002 amounted to $5.5 \%$. Simultaneously with privatisation, the 
enlargement of farms but also their and abandonment for economical reasons were observed.

Transformation in the agricultural sector, the development of agricultural markets and adjustment to the European Union legislation led to the present status of agriculture and irrigation systems. Some positive tendencies are observed concerning economical aspects of irrigation but there are also some unexpected trends: over-production in agriculture and social problems connected with increasing unemployment.

The paper gives an overview of the present status of irrigation in Poland as well as its anticipated development.

\section{STATUS OF IRRIGATION IN POLAND}

Poland is situated in a transitory temperate climate zone, influenced by a mild oceanic climate from the west and a dry continental climate from the east. Climatic conditions in Poland are characterized by considerable weather variability over both long (years) and short (days, weeks) periods of time. The annual mean air temperature is $+7.5^{\circ} \mathrm{C}$. The annual precipitation amounts to $630 \mathrm{~mm}$ and during the growing period (April-September) it reaches on the average $350 \mathrm{~mm}$. In that period, potential evapotranspiration in most areas of the country exceeds precipitation, resulting in water deficit, especially on light soils with low water-holding capacity. The driest regions of Poland include almost entire central region, northwestern and mid-eastern parts of the country. These regions are most threatened by frequent and most severe droughts with annual rainfall less than $300 \mathrm{~mm}$. Low precipitation and high potential evapotranspiration influence water resources and create water management problems in these regions.

Irrigation in Poland has supplemental character; it is used in short periods during the growing season, especially in regions with severe and frequent droughts. Statistically, the irrigation is needed once every three years. There are years when crops cultivated in Poland do not require irrigation during the growing season. In wet years the role of irrigation is marginal. Only in fruit and vegetable farming irrigation is essential every year. Generally, taking into account the whole agricultural area in the country, the role of irrigation in agriculture is marginal because of very small irrigated area $(0.5 \%$ of the total agricultural land area).

Irrigation in Poland plays an important role in mitigating the effects of drought on crop production locally, in areas of light soils with valuable crops, where dry spells are likely to occur, leading to substantial losses in yields. In extremely dry years (e.g. 1992 and 2000) up to $40 \%$ of the country area is affected by drought. Average decrease in crop yield is estimated at $10-40 \%$ as compared to the normal year. 
Till the beginning of the sixties, the main attention in the domain of irrigation in Polish agriculture was paid to the permanent valley grasslands with subirrigation systems, constructed on about $0.5 \mathrm{mln}$ ha. In the middle of the sixties, the attempts to install the irrigating equipment in the field crop cultivation were commenced. Initially, the portable sprinkler systems, semi-portable and stationary systems were used. Gradually with time, the equipment became mechanized; mainly side-roll wheel systems and reel hose travelling guns were in use. In state-owned large farms, the centre pivot pipelines were employed. Due to changes in the national economy after 1989, big state-owned farms were liquidated, large-area sprinkler irrigation systems were abandoned and their use was stopped. At the end of the seventies and in the eighties several forms of micro-irrigation were introduced instead, mainly microsprinkler irrigation in orchards. Parallelly, drip irrigation was widely developing in orchards and greenhouses.

Nowadays, three types of irrigation systems can be distinguished:

1. Systems of gravitational irrigation on permanent grassland in low-lying river plain areas situated in the direct vicinity of lowland rivers on vast reclaimed lowland post-swampy territories, in which sub-irrigation is applied. Such systems consist of a network of ditches and control structures supplemented with a network of drain pipes in some irrigation units. Three techniques for maintaining groundwater level in these systems are used: controlled outflow, subirrigation with a constant water level, sub-irrigation with a regulated water level (groundwater level management) (BRANDYK et al., 1993). Sub-irrigation is used in river valleys on permanent grasslands all over the country, yet mainly in the lowland regions (north and central Poland).

2. Systems with pressure irrigation. These systems include sprinkler and all types of micro-irrigation, i.e. drip, microsprinkler and subsurface irrigation of intensive root, industrial and greenhouse crops, horticultural crops in open air and in orchards (ŁABĘDZKI et al., 2006). Sprinkler irrigation is concentrated chiefly in the western and central part of the country, in regions with relatively low precipitation and with fertile soils. Micro-irrigation systems are developing faster than any other type of pressure irrigation in Poland.

3. Flood irrigation. There are only small areas irrigated by flooding -300 ha in 2004 (Tab. 1). This method of irrigation is used to a very small extent because of great water demand and low irrigation effectiveness.

According to official data (Rocznik statystyczny ochrony środowiska, 2005), border irrigation was also used till the nineties (Tab. 1), but there are some areas where it is still in use (the Ner River valley).

The total area of irrigated land (equipped with irrigation systems - large part of it is not used nowadays) is 452 thousand hectares: 401 thousand hectares of gravitational systems on grasslands and 51 thousand hectares of pumped systems in arable lands (Rocznik statystyczny, 2005). 
Table 1. Irrigated area in Poland and water uptake for irrigation [Statistical..., 2005]

\begin{tabular}{c|c|c|c|c|c}
\hline \multirow{2}{*}{ Year } & \multicolumn{5}{c}{ Irrigation method } \\
\cline { 2 - 6 } & total & sub-irrigation & sprinkling & flood irrigation & border irrigation \\
\hline \multirow{5}{*}{$\begin{array}{c}\text { Irrigated area, ha } \\
1990\end{array}$} & 301500 & 284950 & 10300 & 2550 & 3700 \\
2004 & 80100 & 75600 & 4200 & 300 & - \\
\multicolumn{7}{c}{} \\
1990 & 519 & - & Water uptake, $\mathrm{hm}^{3}$ & & - \\
2004 & 88.5 & 84.5 & - & 0.5 & - \\
\hline
\end{tabular}

The area of irrigated lands has dropped dramatically since the beginning of the nineties, due to changes in national economy and economic conditions in agriculture (from about 300000 ha in 1989-1990 to 80000 in 2004). Irrigated area decreased by $73 \%$ in comparison with the 1990 (Tab. 1). On the country average the area irrigated in 2004 was $0.5 \%$ of the total agricultural land area. In the driest region of Poland - the Kujawsko-Pomorska province $-1.1 \%$ of agricultural land area was irrigated. In the official government publications there is no data on microirrigation but total area under micro-irrigation in Poland can be estimated at about $5000-10000$ ha.

Total water consumption for agricultural and forest irrigation and for filling fish ponds equals about $1 \mathrm{~km}^{3} \cdot \mathrm{y}^{-1}$ and its share in the total water consumption in the national economy is $10 \%$. In 2004, water withdrawal for irrigation was about $89 \mathrm{hm}^{3}$ including $3 \mathrm{hm}^{3}$ of waste waters. Since 1990 water consumption for irrigation has decreased by $83 \%$ (Tab. 1). The decrease in water use since the nineties has been caused by the decrease in irrigated area.

Under the current economic conditions of Polish agriculture irrigation is often an unprofitable measure. That is why the existing irrigation systems and facilities are hardly used. Irrigation facilities undergo degradation. Economic situation in agriculture and a lack of funds in farmers, farmer associations and local government units responsible for amelioration in the catchment are the main reasons for the negligence of the proper use of reclamation systems and facilities, for the cessation of the maintenance and conservation of irrigation system and for controlled water management. Decreasing interest in the utilization of water facilities is observed. Large areas of agricultural lands are abandoned because of decreased interest in fodder production and its market prices. Additionally, land ownership and land structure (small farms, conflicts of interest in the exploitation of water systems that involve the area of several farms) are unfavourable and cause some problems in proper water management.

Sub-irrigation systems are largely degraded and hardly ever used. It can be estimated that about $20 \%$ of irrigation network and facilities are degraded. From the remaining $80 \%$, only about $20 \%$ of existing and working sub-irrigation systems are 
in use every year. It is necessary to reconstruct and modernize these systems. A lack of modernization and improper exploitation of the systems and facilities restrict competent water management and result in decreased crop production.

The process of degradation of irrigation systems concerns also sprinkler irrigation systems in arable land. After the change of the ownership in agriculture the large-area sprinkling systems were degraded. Small irrigation systems have recently become more common in private farms.

Irrigation is considered the most pro-ecological branch of agriculture and reclamation. Presently, the impact of irrigation on environment is negligible. The impact can be significant when intensive sprinkler and micro-irrigation is performed in intensively fertilized cropping. There is some evidence that the extraction of groundwater for sprinkler irrigation could have some negative influence on protected peatlands neighbouring arable lands.

Sub-irrigation in river valleys is an environment-friendly measure. Maintaining appropriate soil moisture of organic soils and suitable water levels in rivers and tributaries as well as in canals and ditches contributes to the protection of peatlands and natural habitats in a river valley by breaking their further degradation and allowing extensive fodder production at the same time.

\section{IRRIGATION WATER REQUIREMENT}

The large variability of meteorological conditions (the periods of severe droughts and torrential rainfalls), soil types and river flows make water demands for crops and irrigation uncertain. Water requirements for irrigation vary considerably in a time scale of a few days and there is no possibility to generate reasonable fixed instructions in the irrigation control systems. The irrigation water requirement is especially high during very dry periods when rapid depletion of soil moisture is observed and water resources become limited at the same time.

Water requirements for irrigation of a given crop depend on meteorological conditions in the growing period and soil moisture retention. In Poland, precipitation in the winter period and the amount of water stored in soil after winter (at the beginning of the growing period) is of great importance. After winter soil moisture content often meets crop water demands till late spring and modifies considerably the irrigation water requirements.

Mean water demand of high yielding crops under climatic conditions of central Poland is estimated at:

- 300-400 $\mathrm{mm}$ for crops of short growing period (to the end of July) and small water demand, e.g. cereals, early potatoes,

- 400-500 $\mathrm{mm}$ for crops of long growing period (to the end of September) and moderate water demands, e.g. potatoes, sugar beet, 
- 500-600 $\mathrm{mm}$ for crops of long growing period (to the end of September) and great water demands, e.g. fodder crops, vegetables.

Taking into account soil moisture retention in the form of total available soil water equal to $100-120 \mathrm{~mm}$ in medium textured soils and the mean precipitation in a growing period equal to $300 \mathrm{~mm}$ in central Poland, one can estimate crop water deficits indicating net irrigation water requirements. It can be assumed that irrigation water demands for most irrigated crops in central Poland are about 50-300 mm in an average year (Tab. 2).

Table 2. Net irrigation water requirement $N$ in a growing period in central Poland

\begin{tabular}{|c|c|c|}
\hline Crop & Growing period & $N, \mathrm{~mm}$ \\
\hline Rye & April - July & $0-50$ \\
\hline Winter wheat & April - July & $60-80$ \\
\hline Oat & April - July & $0-50$ \\
\hline Maize & April - September & $50-70$ \\
\hline Rape & April - July & $20-30$ \\
\hline Alfalfa & April - September & $80-100$ \\
\hline Early potatoes & April - July & $50-100$ \\
\hline Late potatoes & April - September & $100-150$ \\
\hline Pastures & April - September & $90-120$ \\
\hline Yellow lupine & April - July & $100-150$ \\
\hline Vetch & April - July & $200-250$ \\
\hline Sugar beet & April - September & $50-120$ \\
\hline Fodder beet & April - September & $80-150$ \\
\hline Carrot & May - September & $150-200$ \\
\hline Early vegetables & May - July & $50-200$ \\
\hline Late vegetables & May - September & $200-300$ \\
\hline Berry crops & varied & $170-250$ \\
\hline Orchards & varied & $200-400$ \\
\hline Permanent grassland & April - September & $50-150$ \\
\hline
\end{tabular}

On the average, regarding precipitation, water resources should be sufficient to satisfy irrigation demands. However, water deficits can occur in dry years in regions of small water resources, making irrigation impossible. It is estimated that in many regions of Poland, further development of irrigation could be determined and restricted to a great extent by the availability of water resources. In many cases the factor preventing irrigation system is the lack of water due to the co-occurrence of drought and low water tables in rivers and consequently, the decreased useful capacity of lakes and retention reservoirs. 


\section{LEGAL AND INSTITUTIONAL STATUS OF IRRIGATION}

Irrigation systems, facilities and structures belong to land reclamation systems. According to the Polish Water Act (2001), land reclamation facilities are divided into two types. "Basic land reclamation" facilities include canals, small rivers and streams being important for agriculture, hydraulic structures in these streams used for damming water, regulation of discharge, water intake, pumping stations and so on. "Specific land reclamation" facilities include ditches, small water courses for supplying water to irrigation systems, pipelines, sprinkler and micro-irrigation systems.

\section{OWNERSHIP OF IRRIGATION SYSTEMS}

Sprinkler and micro-irrigation facilities and systems are made by individual farmers and are a private possession of farmers, groups of farmers or a private company. Legal status of sub-irrigation systems is more complex. The State Treasury is the owner of "basic" land reclamation facilities. They include basic water facilities such as water structures for damming water, control discharge, weirs, water intakes, reservoirs, canals, primary delivery system. Secondary and tertiary delivery systems including canals, ditches, small water structures and other facilities for distributing water in the field are the possession of farmers through the ownership of land on which these facilities are located.

\section{STATUS OF IRRIGATION MANAGEMENT, OPERATION AND MAINTENANCE}

In the 1990s legal and organisational changes were introduced to prepare for the transition from the management of freshwater resources by voivodship administration within the traditional structures of the territorial division of the country to a river basin based management system. The Water Act legislated by the Polish Parliament in 2001, which is the binding legal document in Poland, takes into account modern principles of water management in river basins and provides greater participation of water users and local governments in water resources management.

There are different institutions that govern and manage irrigation systems at various levels and are responsible for irrigation water supply. Irrigation management is connected with the forms of ownership, the methods of irrigation and the levels of tasks. The data concerning operation and maintenance of irrigation systems and the amount of used water, published in the official statistical yearbooks, are not fully reliable. The main reason for this is that government administration or local authorities do not keep a record of the number of private small irrigation systems and facilities, the irrigated area and the amount of used water. It concerns 
mainly sprinkler irrigation but the operation and maintenance of sub-irrigation systems located on private farms are also not recorded.

Since 1989, when political and social changes in the national economy have started, Poland has devolved a range of water management tasks from state agencies to participatory, autonomous, financially self-supporting organizations. After the forms of property in agriculture had changed, the irrigation management policy has also changed adequately. There has been an upsurge in efforts to transfer management of irrigation systems from government agencies to farmers and farmer organizations. Farmers and organizations of irrigation water users have been increasingly assuming a pivotal role of responsibility and authority for irrigation management.

The above status of irrigation management is more or less stable. It can be regarded that the process of irrigation management transfer has been finished according to the binding law acts, mainly the Water Act.

The issue of land reclamation is treated separately in the new Water Act. Separate chapters are devoted to irrigation, drainage, water associations and flood protection. In the Water Act, water bodies important for regulating water conditions in agriculture are distinguished. Local authorities are responsible for the administration and management of these bodies. Institutional framework for irrigation in Poland includes only water users associations being voluntary farmers' organizations that utilise common irrigation facilities and systems. Legislation regulating the establishment and operation of water users associations is contained in the Water Act.

Farmers are responsible for irrigation infrastructure located in their fields. Local agencies - the Voivodship Councils of Land Reclamation and Water Facilities - functioning on behalf of the Voivode are responsible for irrigation infrastructure being in the ownership of the State Treasury (water delivery facilities; water structures for damming water and controlling discharge; weirs; water intakes; reservoirs, streams and lakes being the source of water for irrigation, canals, primary delivery system).

Arrangement of the plans of irrigation should be considered in accordance with plans of water management in watersheds, the country and provincial development strategies, the plan for land management of a province and the local plans of land management.

Regulations and rules concerning operation and maintenance of irrigation systems include specific references to the forms of ownership, the methods of irrigation and the levels of tasks.

Sprinkler and micro-irrigation systems, being a private possession of farmers, groups of farmers or a private company, are individually managed, operated and maintained by the owners. The use of ground- or surface water by farmers for pres- 
sure (sprinkler, drip) irrigation is an object of the law. Individual decisions for permission to use water for irrigation are based on the Water Act.

Operation and maintenance of sub-irrigation systems are more complex. Subirrigation systems are jointly managed by farmers, farmer associations and agencies. The tasks of operation and maintenance are also done jointly by them.

Farmers are responsible at the tertiary level. They manage irrigation in the field according to their demands. The duty to maintain water structures located in farmers' fields is enforced by the law - The Water Act. Farmers can form water users associations which act at the secondary level. It is their major responsibility to manage most operation and maintenance activities performed in irrigation systems. These organizations are governed and controlled in a democratic manner by those who benefit from and pay for the services they supply. They are financed by their participants through an annual membership fee. Water users associations in Poland have their basis in the Water aw Act, which regulates their establishment and operation.

Local agencies - the Voivodship Council of Land Reclamation and Water Facilities - are the units administering water bodies which, regarding their use for agriculture, are separated from the Regional Water Management Boards. They manage at the main (primary) level. They are responsible for water supply to subirrigation systems and for operation and maintenance of water delivery facilities and streams, lakes, reservoirs and main canals being the source of water for irrigation. They render services for basic land reclamation structures and the maintenance and use of land reclamation structures. Within their competencies, there are building, operating and maintaining flood embankments.

Besides individual farmers' issues, actual determinants of various operation and maintenance activities are strictly connected with the state of water management in agriculture, particularly with the state of amelioration and exploitation of the existing irrigation systems. There are restricted possibilities of proper use of irrigation systems in agricultural areas and simply, there is a negligence of the use of irrigation systems and water facilities. Basic reasons for this situation include:

- the lack of proper conservation of running waters and ditches that does not allow for carrying planned irrigation,

- the lack of instructions and control devices which makes the control of irrigation difficult,

- the lack of financial means to cover the costs of water uptake that decreases the intensity of irrigation,

- the lack of agreements regulating water uptake for irrigation in dry years between responsible agencies and farmers which limits the extent of irrigated areas,

- decreased interest of farmers in crop production that results in agro-technical negligence and affects the effectiveness of management on irrigation objects. 
Because of private land ownership, proper operation and maintenance depends on the farmers' interest and the farmers' awareness of the need to implement the instructions of operation and maintenance. Different actions undertaken are exceedingly difficult since most part of irrigation systems is in private hands and the acceptance and participation of the owners in various projects is indispensable.

\section{FUTURE PERSPECTIVES OF IRRIGATION IN POLAND}

Political and economical changes in Poland, in its early stage, caused considerable reduction of irrigated land. At present, slight increase in the area of irrigated land, especially in vegetable and fruit farming that use drip irrigation, is observed. It is assumed that the development of this type of irrigation will run parallelly to the development and intensification of agriculture. There is no need, except financial subsidies, to undertake any special actions to stimulate development of this type of irrigation. It is expected that increased use of groundwater for this type of irrigation may cause unfavourable changes in the environment. However, it might become necessary to limit groundwater uptake. More difficult situation is observed in irrigation of field crop cultivation and grassland farming. One of the conditions of the development of irrigation is the organisation of training courses, as it is essential to implement appropriate methods of the use of land reclamation systems, especially by means of regulating the groundwater level.

The transformations proceeding in agricultural areas have slowly affected the mentality of rural population, changing also their views on irrigations. During the recent years, three new factors have exerted an accelerating influence on these viewpoints:

- increased frequency and intensity of droughts and long-lasting rain-free periods (3-5 weeks) in Poland, with high insolation and high air temperatures. In the case of water retention deficits in the area it leads to dramatic deficits of water in the soil, which, in consequence, causes meaningful lowering of crops and creates an uncertainty in economic planning of the farm activities,

- the intensification of agricultural production, being forced by the internal domestic and all-European free-market competition; its stabilization is necessary every year because only then it is possible to conclude various contracts with the users of agricultural crops,

- the necessity of reaching high quality of the majority of agricultural products; one of the examples may be the consumable potatoes, especially for collective nutrition; their indispensable qualitative standard (size; shape, equality) may be reached only under the conditions of sprinkler irrigation, i.e. in the conditions of stable optimal soil humidity.

As far as the technique and the irrigation systems are concerned, they are and will be in the nearest future similar to the systems used in other European coun- 
tries. They are and they will include the sprinkling machines in agricultural field cultivations, sprinkling machines and drip irrigation systems in vegetable farming, various micro-irrigation systems in greenhouses and orchards. In the near future, the role of micro-irrigation of intensive root, industrial and greenhouse crops, horticultural crops in open air and orchards in private farms will increase.

On permanent valley grasslands, gravitational sub-irrigation systems will remain in the future as a source of fodder and a way of healthy cattle feeding. They also have a great role in the preservation of biodiversity and organic soils in river valleys.

One may say that it is not the technique which will be the barrier to the development of irrigation in Poland but the economics and the availability of water, in sufficient quantities and of suitable quality.

The challenges for the government, regional councils, local administrations of amelioration and water management, farmer associations and farmers themselves for now and for the nearest future in the field of irrigation in Poland are:

- to restraint decapitalization of irrigation systems,

- to improve and modernize irrigation systems,

- to creation favourable economic conditions in agriculture for the investment, maintenance and performance of irrigation,

- to implement modern energy- and water-saving methods and techniques of irrigation,

- to improve the efficiency of irrigation,

- to optimize water distribution and water management in irrigation systems and in the catchment,

- to implement various measures in order to increase local water resources of good quality and their availability.

The significance of irrigation will increase with the intensification of agriculture e.g. horticulture, orchards, seed crops. Studies show (NYC and POKŁADEK, 2007) that under conditions of climatic and economical changes and considering sustainable development of Polish agriculture, the irrigation area will increase up to $2.1 \mathrm{mln}$ ha, including $1.6 \mathrm{mln}$ ha on permanent grasslands and $0.5 \mathrm{mln}$ ha on arable land and in orchards. MiODUSZEWSKI (2007) writes that 3-4\% of arable lands (without sub-irrigated area) should be irrigated in the near future.

The success of irrigation projects depends strongly on management. There is an increasing conviction that systems operated by water users seem to have higher success than those publicly operated. For this reason there is a tendency of transferring the management of public irrigation districts to the water users (privatisation). Generally, funds are inadequate for the maintenance. There is a number of transformations of institutional arrangements in Poland, which were employed to manage irrigation schemes into more efficient and effective ones. Some schemes involve the transfer of the operation system to local governments through regional 
boards and farmers (water users associations), others are based on involving private sector entities into the management process.

Development of irrigation depends first on the economical situation in agriculture - development of the market for agricultural products. Following factors will stimulate the development of irrigation:

- maintenance and adequate exploitation of the so called "basic land reclamation facilities" including reservoirs and canals maintained by the State,

- popularisation among farmers and implementation of modern irrigation systems and water-saving technologies through training courses,

- creation of legal, financial and institutional possibilities for regional water supply systems for irrigation,

- activation of farmers' participation in the planning of irrigation development and water resources management, with special emphasis on activities oriented on the protection of water-related ecosystems and improvement of ecological status of surface waters,

- elaboration of new rules for co-operation leading to undertaking common actions by agencies responsible for irrigation,

- establishing boards (organizations) responsible for integrated water management in small river catchments, satisfying needs of all water users, including irrigation systems.

Different measures appropriate for making irrigation effective and environmental-friendly should be undertaken., The most important among them are: the development of irrigation systems as an element of integrated water management system in a catchment, development and use of the technology of sub-irrigation to protect wetlands and organic soils through regulated run-off, improving the operation of irrigation systems through automation and mechanization, development of appropriate irrigation systems and practices under different soil, plant and climatic conditions in order to achieve optimum yields with high water use efficiency, improving the quantity and quality of yields through improved agrotechniques and the introduction of new varieties, saving water and fertilizers through the scheduling and monitoring of irrigation and fertilization, optimization of pesticides and nutrients application adequately to the natural pedoclimatic conditions of the area and water supply, fertigation.

Irrigation in Poland is - and should be - seen as an element of integrated water management in a river catchment. So the problems, objectives, options and vision in irrigation should be seen in the context of water management. The scale of problems to be solved for upgrading the management of water resources to the required state (taking full account of the principles of sustainable development) has been well recognized in Poland. 


\section{REFERENCES}

1. BRANDYK T., SkAPSKi K., SZATYlowiCZ J., 1993. Design and operation of drainage-sub-irrigation systems in Poland. Irrigation and Drainage Systems, 7: 173-187.

2. ŁABĘDZKI L., KUŹNIAR A., LiPIŃSKI J., MiOdUSZEWSKI W., 2006. Irrigation management transfer in European countries - Polish report. In: W. Dirksen, W. Huppert (eds.) Irrigation Sector Reform in Central and Eastern European Countries. GTZ (Deutsche Gesellschaft für Technische Zusammenarbeit), Eschborn, Germany; ICID, New Delhi, India: 329-383.

3. MioduszewsKi W., 2007. Uwarunkowania rozwoju melioracji wodnych w świetle Ramowej Dyrektywy Wodnej. (Determinants of land reclamation development in the background of the Water Framework Directive). Wiad. Melior. nr 2: 51-55.

4. NyC K., PoKŁadeK R., 2007. Celowość i kierunki rozwoju melioracji w Polsce. (Aims and trends of development of land reclamation in Poland). Wiad. Melior. nr 3: 101-105.

5. Rocznik statystyczny (Statistical Yearbook), 2005. Warszawa, GUS.

6. Rocznik statystyczny ochrony środowiska (Statistical Yearbook of Environment), 2005. Information and statistical papers. Central Statistical Office. Warszawa, GUS.

7. Prawo wodne (Water Act), 2001. Ustawa z dnia 18 lipca 2001 r. Dz.U. 2005 nr 239 poz. 2019.

\section{STRESZCZENIE}

\section{Nawodnienia w Polsce - obecny stan po reformach w rolnictwie i przyszly rozwój}

Słowa kluczowe: eksploatacja, nawadnianie, rolnictwo, systemy nawodnień, utrzymanie

W pracy przedstawiono obecny stan nawodnień w Polsce, jak również trendy i perspektywy nawodnień. Nawodnienia w Polsce mają charakter interwencyjny, likwidujący okresowy niedobór opadów. W dolinowych trwałych użytkach zielonych stosuje się nawodnienia podsiąkowe z systemem rowów, w uprawach polowych - deszczowanie, w warzywnictwie na otwartych polach - deszczowanie i nawodnienia kroplowe, w sadownictwie i w uprawach szklarniowych - mikrodeszczowanie i nawodnienia kroplowe.

Po zmianach własnościowych $\mathrm{w}$ rolnictwie wielkoobszarowe deszczownie uległy znacznej lub całkowitej dewastacji. Systemy nawodnień podsiąkowych są również $\mathrm{w}$ znacznym stopniu zdewastowane i wykorzystywane w niewielkim stopniu. W celu zwiększenia efektywności tych systemów, należy je odbudować i zmodernizować. W ostatnich latach obserwuje się rosnącą rolę mikronawodnień w sadownictwie i w polowych uprawach warzywniczych, w prywatnych gospodarstwach rolnych nastawionych na taką produkcję, w których nawodnienia gwarantują stabilizację plonu dobrej jakości na poziomie przynoszącym zysk. Taki trend będzie się nasilał w najbliższych latach. 
W aktualnych warunkach ekonomicznych rolnictwa w Polsce nieopłacalne jest nawadnianie prawie wszystkich upraw polowych, z wyjątkiem ziemniaków. Opłacalne jest natomiast nawadnianie upraw warzywniczych i sadowniczych.

Urządzenia i systemy nawodnień ciśnieniowych są zarządzane przez ich właścicieli, tj. rolników, grupy rolników (producenckie) lub prywatne firmy. Systemy nawodnień grawitacyjnych w zakresie melioracji szczegółowych są zarządzane przez rolników - właścicieli gruntów i urządzeń na nich się znajdujących bądź przez spółki wodne, jeśli ci rolnicy są członkami spółki. Realizują oni zadania z zakresu prowadzenia nawodnień i utrzymania urządzeń. W zarządzaniu nawodnieniami grawitacyjnymi uczestniczą jeszcze wojewódzkie zarządy melioracji i urządzeń wodnych, które są odpowiedzialne za dostarczenie wody do systemów nawodnień, jak również eksploatację i utrzymanie urządzeń melioracji podstawowych temu służącym (budowli piętrzących, budowli ujęciowych, kanałów, będących źródłem wody do nawodnień).

Dalszy rozwój nawodnień w Polsce może być w znacznym stopniu ograniczony, poza niekorzystnymi uwarunkowaniami ekonomicznymi, zasobnością źródeł wody do nawodnień, a w przypadku mikronawodnień - również jakością wody. Już obecnie w regionach (np. na Kujawach), wyposażonych w urządzenia nawadniające, w suchych latach nie można prowadzić nawodnień z powodu zbyt niskich stanów wody w ciekach, jeziorach i małych zbiornikach sztucznych, będących źródłem wody do nawodnień.

Reviewers:

Received 05.03.2007

Prof. Edward Pierzgalski

Prof. Czesław Przybyła 